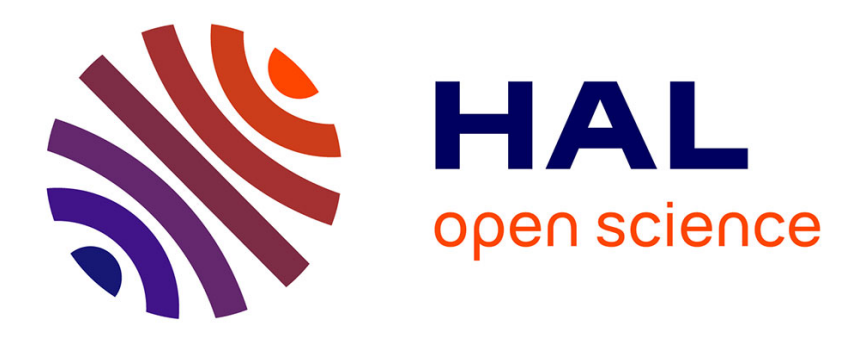

\title{
Insect Molecular Virology: Advances and Emerging Trends.
}

\author{
Elisabeth A. Herniou
}

\section{To cite this version:}

Elisabeth A. Herniou. Insect Molecular Virology: Advances and Emerging Trends.. Quarterly Review of Biology, 2020, pp.547. hal-03010507

\section{HAL Id: hal-03010507 https://hal.science/hal-03010507}

Submitted on 17 Nov 2020

HAL is a multi-disciplinary open access archive for the deposit and dissemination of scientific research documents, whether they are published or not. The documents may come from teaching and research institutions in France or abroad, or from public or private research centers.
L'archive ouverte pluridisciplinaire HAL, est destinée au dépôt et à la diffusion de documents scientifiques de niveau recherche, publiés ou non, émanant des établissements d'enseignement et de recherche français ou étrangers, des laboratoires publics ou privés. 
and genetic engineering. He applauds the efforts to do somatic repair for thousands of single gene mutational defects in humans but is ambivalent on how it should or should not be used in the germ line or through stem cells. He feels the ethical issues are not clear cut and these will require sorting as usage spreads in medical fields and as our fears of Nazi eugenics are distinguished from choices we otherwise accept as assortative mating in our own partners for raising a family. McHughen answers every objection to genetically modified foods (GMOs).

In all of these chapters he provides references to databases, agency studies, and court decisions that will be useful for teachers to follow in creating lectures. This will be a handy review for graduate students preparing for their qualifying oral exams and the author takes the time to understand the opposing views to DNA in agricultural, pharmaceutical, medical, or other applications of DNA in our lives. Because it is not a narrative like most popularizations it takes time to read the book and adjust to its quantalike presentations, which reminds me of the questionand-answer discussions in international meetings of scientists.

Elof Axel Carlson, Biochemistry E Cell Biology, Stony Brook University, Stony Brook, New York and Institute for Advanced Study, Indiana University, Bloomington, Indiana

Insect Molecular Biology: Advances ANd EmergING TRENDS.

Edited by Bryony C. Bonning. Norfolk (United Kingdom): Caister Academic Press. $\$ 319.00$ (paper). vi + 264 p.; ill.; index. ISBN: 978-1-912530-08-3 (pb); 978-1-912530-09-0 (eb). 2019.

This multiauthored book elegantly brings together international leading authors for 11 chapters on advanced and emerging topics in insect molecular virology. This field has long been driven by pest control and biotechnological applications. Cutting-edge techniques, including next-generation sequencing and cryo-electron microscopy, have revolutionized and vastly broadened our understanding of the biodiversity of viruses associated with insects, as well as their interactions scaling from molecular to entire organisms. This is therefore a timely publication that sets the basis for future research directions.

Chapter 1 presents cautionary tales on insect virus discovery as there is currently a large knowledge gap between genetic data and biological validation. This is exemplified by recent discoveries on the virome of such emblematic insect models as Drosophila, mosquitoes, and honey bees. Indeed, the "-omics" boom has led to the discovery of a multitude of viral sequences, including many that are integrated into insect host genomes, and that could be harnessed for disease vector control in the future, as described in Chapter 2. However, insects lay out a complex antiviral defense. Several signaling pathways such as the Toll and IMD pathways as well as response pathways relying on siRNA, piRNA, or miRNA are now well-characterized, and Chapters 3 and 4 elaborate on cellular detection of viruses and RNAi modulation that clarified these central topics. The focus on current research advances on particular virus families, such as dicistroviruses (Chapter 5 ) or tetraviruses (Chapter 7) as well as plant viruses transmitted by insect (Chapter 6) further reveal the intricacies of viral/cellular interactions and how much we still need to uncover on insect viruses. I particularly appreciated the diversity of the insect and virus models presented in each chapter, which take readers from tiny exogenous tetravirus infections to all tested multicellular organisms in Chapter 7 to the endogenous polydnaviruses that evolved from the domestication of large DNA viruses by parasitoid wasps in Chapter 8. Lastly, given the importance of baculoviruses in laying out the foundation of insect molecular virology, it was only fair to dedicate the last three chapters to recent advances on their molecular biology and applications. Chapter 9 reviews the functions of all core and essential baculovirus genes, which is a crucial prerequisite to the construction and development of synthetic viruses and that would open new avenues for biotechnological applications. Chapters 10 and 11 give accounts of the recent technical advances in cell culture and baculovirus vector design that greatly improved and stabilized protein expression and baculovirus surface display of immunogens for vaccination. In this day and age, this is a powerful reminder that basic research, including insect viruses, can lead to innovative therapeutical applications and is thus of paramount importance for human health.

In summary, this is an excellent primer on some of the most exciting and innovative research in insect molecular virology. I would recommend it to all researchers and students interested in insect viruses and advanced biotechnological applications.

Elisabeth Herniou, Institut de Recherche sur la Biologie de I'Insecte, UMR 7261 CNRS, Université de Tours, Tours, France

Celllular Biophysics and Modeling: A Primer on the Computational Biology of Excitable Cells.

By Greg Conradi Smith. Cambridge and New York: Cambridge University Press. \$125.00 (hardcover); \$49.99 (paper). xii + 382 p.; ill.; index. ISBN: 978-1-10700536-5 (hc); 978-0-521-18305-5 (pb). 2019. 